\title{
Do First Impressions Count? Perceived Nonverbal Behaviors Associated with Social Acceptance in University Students
}

\author{
José Maria Montiel, Daniel Bartholomeu, Geraldo Antônio Fiamenghi Jr., \\ Fabiano Gutierrez Franco, Gleiber Couto, Fernando Pessotto, João Carlos Caselli Messias
}

Nucleo de Pesquisa em Saúde e Desempenho Humano Centro Universitario FIEO, UNIFIEO/SP, Osasco, Brasil

Email: d_bartholomeu@yahoo.com.br

How to cite this paper: Montiel, J. M., Bartholomeu, D., Fiamenghi Jr., G. A., Franco, F. G., Couto, G., Pessotto, F., \& Messias, J. C. C. (2017). Do First Impressions Count? Perceived Nonverbal Behaviors Associated with Social Acceptance in University Students. Psychology, 8, 1378-1389.

https://doi.org/10.4236/psych.2017.89090

Received: June 15, 2017

Accepted: July 18, 2017

Published: July 21, 2017

Copyright $\odot 2017$ by authors and Scientific Research Publishing Inc. This work is licensed under the Creative Commons Attribution International License (CC BY 4.0).

http://creativecommons.org/licenses/by/4.0/

\begin{abstract}
This study aims to analyze the relationship between non-verbal behavior of social interaction and acceptance and rejection in college, making sure that there are differences from beginning to end of the half as the acceptance and social rejection to study and do well as nonverbal behaviors evaluated at the beginning of the semester remains similar to the final acceptance and rejection in these assessments. They studied 175 college students of business schools (56.5\%) and logistics of a large university in São Paulo, with $41 \%$ women. All of these students responded to the tests at the beginning and the end of June after signing the consent form. About $35 \%$ of the subjects were in the second year of their courses and students participated in the research first to seventh year of their courses. It developed a protocol in which it asks the student indicate a person who would like to study in the group and justify your choice from your perception of that person in nonverbal behaviors, namely, the look, voice content, voice quality, gestures hands, smile, body posture, tone of voice. In general, analyzing the behavior alone, they did not show differences in the perception of the beginning to the end of semester. However, how these were listed as reasons for the acceptance and social rejection to study and come out changed the beginning to the end of term, indicating that the coexistence of a semester enables a change in accepted motives and social rejection in the group.
\end{abstract}

\section{Keywords}

First Impressions, Nonverbal Behavior, Educational Psychology, College

\section{Introduction}

Latha (2014) believes communication to be the transference of information to 
one person to another; as such, people spend $75 \%$ of their time in interpersonal communication, a significant part of which is nonverbal (body movements, eye contact, facial expressions). In fact, nonverbal communication refers to the transference of meanings through body language, space, time and paralinguistic elements, other than written or spoken language. Nonverbal communication is essentially less structured than verbal, non-linear, spontaneous and complementary to speech (Kouros \& Cummings, 2011).

Personal appearance, including the way people dress, is one of the basis for first impressions, even before we introduce ourselves. Body posture, defined as the body position of the other, is different from gestures (the actual movements) and refers to how we place and keep our body, as well as the body fitness, related to feelings, personality traits such as trust, openness, or submission, and must correspond to context or situation's normal expectancy (Latha, 2014). Body gestures are movement performed with a member, especially the hands, to express, confirm, emphasize, or follow an attitude or intention. Gestures are signs of body language and are emblematic as the signs of good-bye, or the victory " $\mathrm{V}$ ", for example. Facial expressions are also important nonverbal communication channels as they constantly change and are constantly monitored during communication. Eye movements involved in facial expressions are important aspects of nonverbal elements and the frequency of visual contact may suggest interest or boredom, or even suggest treason or deceit (Aviezer, Trope, \& Todorov, 2012; Kouros \& Cummings, 2011; Latha, 2014). About 93\% of communications are nonverbal, being $38 \%$ attributed to nonverbal signs such as voice volume, pitch, speed, and 55\% to visual contact (Gallo, 2007; Neuliep, 2003).

Part of those behaviors' processing is not conscious. While talking to someone, conscious thinking is alert to words and verbal communication to respond, as nonverbal elements are subconsciously processed. That is the way mirror neurons adapt in order to send information and to alert whether there is something wrong with the communication, as mirror neurons are involved in survival strategies, helping humans sharing knowledge, learning art, fights or compassion based in others' body language (Reiman, 2008).

Every time a person meets another one, a first impression is created, consisting in initial judgements based on nonverbal communication signs. Bierman \& Wargo (1995) explain that Todorov and Willis' studies pioneered in revealing that an impression from a strange face takes a tenth of a second to be formed and prolonged exposure will not significantly alter those impressions (Mcaleer, Todorov, \& Belin, 2014; North, Todorov, \& Osherson, 2012; Stewart, Ajina, Getov, Bahrami, Todorov, \& Rees, 2012). Based on that, the social preferences, confidence and wish to keep interactiong with people are defined. Actually, people make relatively precise assessment in less than one-minute observations and as such, people must prove themselves decent, genuine, and trustful via one tenth of a second nonverbal communication, otherwise the interaction might not persist (Kouros \& Cummings, 2011).

Previously to verbal communication, human beings make judgements to as- 
sure survival; in fact, accurate first impressions might be done to allow survival. Kouros and Cummings (2011) indicate a series of questions that must be answered to understand first impressions, such as why do we use first impressions and how do we do it; are they precise; are there people who perform better than others in first impressions do?

Many cognitive aspects are involved to facilitate specific ways of adjustment to social behaviors (Bartholomeu \& Montiel, 2013). As social interactions evolved, new benefits and threatens appeared and early cognitive detection alert against possible damages. Cummings (2011) suggests that first impressions tend to be more negative, as primarily the basic psychological mechanisms might be related with danger detection, that are neutralized when potentially hazardous intentions are inferred. Therefore, negative impressions persist even with contradictory information, and positive impressions require more evidence and can even be reverted to negative with additional information (Bartholomeu, Carvalho, Silva, Miguel, \& Machado, 2011). The tendency to form simple and quick first impressions is instinctive and consequently, individual differences are difficult to establish (Ambady \& Skowronski, 2008). People who are more precise in developing first impressions are less prone to depressive symptoms, less social anxiety, and shyness; they also are more socially competent, opened to experiences, confident, more expressive, and communicative. Another feature is empathy, as they are more capable to establish precise peers' body language, as well as considered sources of advice and safety, warm, compassionate, less hostile and less rebellious (Ambady \& Skowronski, 2008; Blake, Kim \& Lease, 2011; Funder \& Harris, 1986; Kudesia \& Elfenbein, 2013). It is interesting to observe that the ability of forming first impressions is not correlated to inteligence, but with nonverbal communication knowledge, related to social intelligence (Borod, Pick, Hall, Sliwinski, Madigan, Obler, Welkowitz, Canino, Erhan, Goral, Morrison, \& Tabert, 2000; Davitz, 1964; Davis \& Kraus, 1997).

Kraus, Oveis, Allison, Young, Tauer and Keltner (2014) examined group hierarchy and suggested that subjects acquire respect and admiration when involved in behaviors that affect others' judgements related to group values. Tetlock (1983) observed that people's attribution is affected by pressures in justifying impressions and decrease the primary effects of subjects' first perception, affecting the way people decode and process information. Dockrell and McShane (2000) analyzed the effects of nonverbal cues and first impressions in interviews, and results showed a significant interaction between the kind of interview and nonverbal cues, especially in non-structured interviews.

Studies focusing on impressions and nonverbal behaviors are more frequent in business and marketing (Kudesia \& Elfenbein, 2013), but more restrict in Education (Ames, 2008; Greenfield \& Quiroz, 2013; Titkova, Ivaniushina, \& Alexandrov, 2013; Wentzel, 2009). No studies relating nonverbal behaviors to sociometry (social acceptance and rejection in school) were identified, as well as studies investigating the consistence of first impressions in school contexts, and university students. 
Following the assumptions previously described, this study aimed to verify the relations between acceptance and rejection in university students based on nonverbal behavior, since they have a strong impact on the formation of first impressions in social relations. Thus, we tried to compare the impressions formed at the beginning and end of the semester regarding acceptance and rejection to study and leave university students.

\section{Method}

\subsection{Participants}

The sample consisted of 175 students, female (41\%) and male (59\%) enrolled in business administration (56.5\%) and logistic courses at a São Paulo (Brazil) Metropolitan area University, assessed at the beginning and the end of term. Participants came from first to $7^{\text {th }}$ periods of their courses.

The choice of these classes was due to the fact that they attended a common core discipline taught at the university, in which students of different grades participated and they did not attend the same rooms before entering this discipline. This course was taught in two classes containing 80 and 95 students, respectively.

\subsection{Instruments}

\section{Checklist of Nonverbal Behaviors}

This measure seeks to capture the acceptance or rejection of a student by his or her peers. For this, it was first requested that each participant nominate a colleague who would choose to study. The participant should justify his/her response from the perception of the person chosen in non-verbal behaviors, such as the look, voice content, voice quality, hand gestures, smile, body posture, tone of voice (Caballo, 2000). Each behavior was rated on a scale of 1 to 5, with " 1 " being a perception of that behavior as being inappropriate and " 5 " adequate. This procedure was applied to the positive choices, that is, acceptance to estuar and leaving and negative, namely, rejection in these same situations.

\subsection{Procedures}

Students responded to the "Checklist of Nonverbal Behaviors" at the beginning of the semester, when they did not know each other yet. After 6 months, the procedure was repeated with the same participants. Each application lasted an average of 20 minutes.

\section{Results and Discussion}

Firstly, results from the protocols at the beginning of the term and its end in terms of acceptance and rejection to "study with" and "hang out with" were compared. The analyzes were carried out in the software Statistical Package for Social Sciences (SPSS), version 20. Table 1 shows descriptive statistics for the acceptance situation of "study with". 
Table 1. Nonverbal behaviors predictive of acceptance to "study with" (beginning of term).

\begin{tabular}{|c|c|c|c|c|c|c|c|c|}
\hline \multicolumn{9}{|c|}{ Coefficients $^{\mathrm{a}}$} \\
\hline & \multirow{2}{*}{ Model } & \multicolumn{2}{|c|}{$\begin{array}{c}\text { Unstandardized } \\
\text { Coefficients }\end{array}$} & \multirow{2}{*}{$\begin{array}{c}\begin{array}{c}\text { Standardized } \\
\text { Coefficients }\end{array} \\
\text { Beta }\end{array}$} & \multirow[t]{2}{*}{$\mathrm{t}$} & \multirow{2}{*}{ Sig. } & \multicolumn{2}{|c|}{ Collinearity Statistics } \\
\hline & & B & Std. Error & & & & Tolerance & VIF \\
\hline \multirow{6}{*}{22} & (Constant) & 0780 & 0336 & & 2.324 & 0021 & & \\
\hline & Posture & 0258 & 0087 & 0262 & 2.974 & 0003 & 0591 & 1.692 \\
\hline & Gesture & -0204 & 0096 & -0199 & -2.118 & 0035 & 0519 & 1.926 \\
\hline & Speed & 0182 & 0078 & 0194 & 2.345 & 0020 & 0669 & 1.495 \\
\hline & Content & 0181 & 0094 & 0181 & 1.934 & 0055 & 0527 & 1.898 \\
\hline & Personal Attention & -0147 & 0081 & -0173 & -1.810 & 0072 & 0502 & 1.994 \\
\hline \multicolumn{9}{|c|}{${ }^{\mathrm{a} D e p e n d e n t ~ V a r i a b l e: ~ a c c e p t a n c e-s t u d y i n g ~ w i t h ~}$} \\
\hline
\end{tabular}

Source: Prepared by the authors.

There were no significant differences in the responses' means of each indicator pretest and posttest, except rejection to "study with", showing more rejection after 6 months. Hence, the answer to "Do first impressions count?" seem to be "yes", as every behavior considered by the participants at the beginning of the term were stable after some months of contact. Results are in accordance to literature, as other studies also showed initial perceptions to be stable in time (Bierman \& Wargo, 1995; Mcaleer, Todorov, \& Belin, 2014; North, Todorov, \& Osherson, 2012; Stewart et al., 2012). In addition, rejection being more observed agrees to literature, as evolutionary psychological mechanisms are involved with alert and danger detection (Bartholomeu \& Montiel, 2013). The increase of rejection after six months may be explained by the fact that negative impressions are more persistent, even when receiving contradictory information, and positive impressions can be easily transformed in negative ones, when new information appear (Kouros \& Cummings, 2011).

However, measure dispersion was high, and correlations between pretest and posttest variables were low, leading to the possibility that many people were not classified in the same way as their classmates, as well as that not all participants who were accepted in pretest had the same assessment in posttest, despite similar means. Thus, a model was created, including measures of nonverbal behavior and acceptance and rejection in the beginning and end of term, to investigate whether the same behaviors would be associated to acceptance and rejection to "study with" and "hang out with" in the beginning (when people did not know each other) and after a period of contact. Analysis employed nonverbal behaviors classified in each period (term beginning and end) as independent variables and acceptance and rejection to "study with" and "hang out with" as dependent variables, using the backward method to insert variables into the model.

Concerning acceptance to "study with" in the beginning of the term, the final statistic significant model included variables posture, gestures, speech speed and content. The observed tendency suggests that a better posture, as well as speech 
speed and adequate content are associated to acceptance to study with; too many gestures were negatively associated to that variable $(\mathrm{F}(5,192)=4.89 ; p=0.000)$. Acceptance to study with at the end of term was not significantly associated to any nonverbal behavior $(\mathrm{F}(5,192)=2.059 ; p=0.093)$. Therefore, acceptance to study with tended to be associated to a first impression of posture, defined by Latha (2014) as position and maintenance of the body in front of the other, as well as its physical structure, related to personality traits such as trustfulness, openness, or submission. Speech speed and adequate content were also paralinguistic elements related to acceptance in first impression (Greenfield \& Quiroz, 2013; Latha, 2014; Titkova, Ivaniushina, \& Alexandrov, 2013).

Concerning rejection to "study with" in the beginning of the term, significant variables were speech volume, duration and content; the more adequate the volume and content, the less rejection to "study with" and the higher the speech duration, more rejection was observed $(\mathrm{F}(5,192)=4.72 ; p=0.003)$. At the end of the term, orientation, personal appearance, intonation, speech time and fluent were significant $(\mathrm{F}(5,192)=5.52 ; p=0.000)$.

It seems that, as people meet, paralinguistic elements tended to associate to rejection to "study with" and as interpersonal contact increases, other paralinguistic elements are observed as relevant, such as speech duration, as well as other behavioral features such as orientation and appearance were likely to reduce rejection (Table 2). Apparently, the amount of information gathered with

Table 2. Nonverbal behaviors predictive to rejection to study with at the beginning of the term and at its end.

\begin{tabular}{|c|c|c|c|c|c|c|c|c|}
\hline \multicolumn{9}{|c|}{ Beginning of Term } \\
\hline & \multirow[t]{2}{*}{ Model } & \multicolumn{2}{|c|}{$\begin{array}{c}\text { Unstandardized } \\
\text { Coefficients }\end{array}$} & \multirow{2}{*}{$\begin{array}{c}\begin{array}{c}\text { Standardized } \\
\text { Coefficients }\end{array} \\
\text { Beta }\end{array}$} & \multirow[t]{2}{*}{$\mathrm{t}$} & \multirow[t]{2}{*}{ Sig. } & \multicolumn{2}{|c|}{$\begin{array}{c}\text { Collinearity } \\
\text { Statistics }\end{array}$} \\
\hline & & $\mathrm{B}$ & Std. Error & & & & Tolerance & VIF \\
\hline \multirow{4}{*}{24} & (Constant) & 4.244 & 0500 & & 8.493 & 0000 & & \\
\hline & Speech Volume & -.361 & 0172 & -0160 & -2.094 & 0038 & 0800 & 1.251 \\
\hline & Speech Duration & .407 & 0234 & 0175 & 1.743 & 0083 & 0466 & 2.147 \\
\hline & Content & -.632 & 0237 & -0260 & -2.670 & 0008 & 0494 & 2.022 \\
\hline \multicolumn{9}{|c|}{ End of Term } \\
\hline & Model & \multicolumn{2}{|c|}{$\begin{array}{c}\text { Unstandardized } \\
\text { Coefficients }\end{array}$} & $\begin{array}{c}\text { Standardized } \\
\text { Coefficients }\end{array}$ & $\mathrm{t}$ & Sig. & \multicolumn{2}{|c|}{ Collinearity Statistics } \\
\hline & & $\mathrm{B}$ & Std. Error & Beta & & & Tolerance & VIF \\
\hline \multirow{7}{*}{21} & (Constant) & 4.826 & 0.572 & & 8.436 & 0000 & & \\
\hline & Gaze & -0430 & 0231 & -0241 & -1.863 & 0066 & 0492 & 2.034 \\
\hline & Orientation & -0598 & 0240 & -0323 & -2.496 & 0014 & 0492 & 2.032 \\
\hline & Gestures & 0857 & 0225 & 0489 & 3.810 & 0000 & 0501 & 1.998 \\
\hline & Intonation & 0628 & 0279 & 0383 & 2.251 & 0027 & 0285 & 3.509 \\
\hline & Fluence & -0585 & 0263 & -0345 & -2.223 & 0029 & 0342 & 2.924 \\
\hline & Speech duration & -0625 & 0269 & -0362 & -2.320 & 0023 & 0340 & 2.945 \\
\hline
\end{tabular}

Source: Prepared by the authors. 
contact and more detailed observation of nonverbal behaviors tended to include new elements as justifications for social rejection to "study with" (Kouros \& Cummings, 2011).

Acceptance to "hang out with" was significantly related to smile and speech content in the beginning of the $(\mathrm{F}(5,192)=6.20 ; p=0.000)$, as more interesting content minimized the acceptance to hang out with, and smiles tended to increase that acceptance. At the end of the term, significant behaviors were distance, physical proximity, speech volume $(\mathrm{F}(5,192)=3.40 ; p=0.003)$. Paralinguistic elements tended to reduce acceptance to "hang out with", despite being observed as adequate (Table 3 ). While initially smile tended to be associated to acceptance to "hang out with", after some months, physical proximity was more significant. Perhaps paralinguistic elements are picked and used in building first negative impressions, when compared to visual elements (Kouros \& Cummings, 2011).

Concerning rejection to "hang out with" in the beginning of the term, the only significant variable was smiles $(\mathrm{F}(5,192)=11.41 ; p=0.001)$, meaning that the

Table 3. Nonverbal behaviors predictive to acceptance to "hang out with" in the beginning of the term and at its end.

\begin{tabular}{|c|c|c|c|c|c|c|c|c|}
\hline \multicolumn{9}{|c|}{ Beginning of Term } \\
\hline & \multirow{2}{*}{ Model } & \multicolumn{2}{|c|}{$\begin{array}{l}\text { Unstandardized } \\
\text { Coefficients }\end{array}$} & \multirow{2}{*}{$\begin{array}{c}\begin{array}{c}\text { Standardized } \\
\text { Coefficients }\end{array} \\
\text { Beta }\end{array}$} & \multirow{2}{*}{$\mathrm{T}$} & \multirow{2}{*}{ Sig. } & \multicolumn{2}{|c|}{ Collinearity Statistics } \\
\hline & & B & Std. Error & & & & Tolerance & VIF \\
\hline \multirow{4}{*}{24} & (Constant) & 1.250 & 0.352 & & 3.549 & 0000 & & \\
\hline & Smiles & 0191 & 0075 & 0187 & 2.543 & 0012 & 0866 & 1.155 \\
\hline & $\begin{array}{c}\text { Personal } \\
\text { Appearance }\end{array}$ & 0134 & 0075 & 0133 & 1.785 & 0076 & 0834 & 1.198 \\
\hline & Content & -0230 & 0068 & -0248 & -3.407 & 0001 & 0878 & 1.139 \\
\hline \multicolumn{9}{|c|}{ End of Term } \\
\hline \multirow{2}{*}{\multicolumn{2}{|c|}{ Model }} & \multicolumn{2}{|c|}{$\begin{array}{l}\text { Unstandardized } \\
\text { Coefficients }\end{array}$} & $\begin{array}{c}\text { Standardized } \\
\text { Coefficients }\end{array}$ & \multirow[t]{2}{*}{$\mathrm{T}$} & \multirow[t]{2}{*}{ Sig. } & \multicolumn{2}{|c|}{ Collinearity Statistic } \\
\hline & & B & Std. Error & Beta & & & Tolerance & VIF \\
\hline \multirow{8}{*}{20} & (Constant) & 2.026 & 0.354 & & 5.719 & 0.000 & & \\
\hline & Gaze & 0169 & 0096 & 0220 & 1.764 & 0.081 & 0581 & 1.722 \\
\hline & $\begin{array}{l}\text { Distance/ } \\
\text { Physical } \\
\text { Contact }\end{array}$ & 0232 & 0091 & 0346 & 2.554 & 0.012 & 0491 & 2.035 \\
\hline & $\begin{array}{c}\text { Distance/ } \\
\text { Physical } \\
\text { Contact post }\end{array}$ & -0152 & 0084 & -0224 & -1.809 & 0.074 & 0588 & 1.699 \\
\hline & $\begin{array}{c}\text { Voice } \\
\text { Volume post }\end{array}$ & -0224 & 0098 & -0296 & -2.291 & 0.024 & 0541 & 1.850 \\
\hline & Clarity post & -0232 & 0124 & -0326 & -1.867 & 0.065 & 0296 & 3.383 \\
\hline & Clarity post & 0238 & 0116 & 0333 & 2.045 & 0.044 & 0341 & 2.931 \\
\hline & Content post & -0218 & 0120 & -0274 & -1.821 & 0.072 & 0399 & 2.506 \\
\hline
\end{tabular}

Source: Prepared by the authors. 
perception of adequate smiles tend to reduce rejection to "hang out with". At the end of the term, facial expression, gaze and personal attraction were significantly associated with rejection to "hang out with" $(\mathrm{F}(5,192)=9.34 ; p=0.001)$.

It may be observed that variables that explained acceptance and rejection in the beginning of the term, did not sustain at the end of the term. Thus, although the means of the same assessments being constant for the same subjects, the covariation of those variables (nonverbal behavior and social acceptance and rejection) is not the same in the beginning of the term and at its end. Those results indicate that other aspects such as personality, human values, or other group variables may be involved (Kraus, Oveis, Allison, Young, Tauer, \& Keltner, 2014; Blake, Kim, \& Lease, 2011; Kudesia \& Elfenbein, 2013; Funder \& Harris, 1986; Ambady \& Skowronski, 2008). There is a possibility that the first imppression keeps constant at the end of the term, but only resignified based in new perceptions of nonverbal behaviors due to more contac and interaction (Kouros \& Cummings, 2011).

Another analysis was conducted to identify nonverbal behaviors observed in the beginning of the term that could explain acceptance and rejection at the end of the term, and allow for some predictive power of those behaviors in the beginning, to minimize social rejection and maximize acceptance (Table 4). Concerning rejection to "hang out with" at the end of the term, facial expression, personal attention and response to questions in the beginning were significantly associated $(\mathrm{F}(5,192)=4.96 ; p=0.004)$. Results indicate that more agreeable facial expressions and more adequate answers to questions in the beginning of the term, when people did not know each one very well, tended to reduce rejection to "hang out with" after six months of contact. Personal attention, although ade-

Table 4. Nonverbal behaviors predictive of rejection to "hang out with" in the beginning of the term and at its end.

\begin{tabular}{|c|c|c|c|c|c|c|c|c|}
\hline \multicolumn{9}{|c|}{ Beginning of Term } \\
\hline & \multirow{2}{*}{ Model } & \multicolumn{2}{|c|}{$\begin{array}{l}\text { Unstandardized } \\
\text { Coefficients }\end{array}$} & \multirow{2}{*}{$\begin{array}{c}\text { Standardized } \\
\text { Coefficients }\end{array}$} & \multirow{2}{*}{$\mathrm{t}$} & \multirow{2}{*}{ Sig. } & \multicolumn{2}{|c|}{ Collinearity Statistics } \\
\hline & & B & Std. Error & & & & Tolerance & VIF \\
\hline \multirow{2}{*}{26} & (Constant) & 3.095 & 0.317 & & 9.762 & 0000 & & \\
\hline & Smiles & -0398 & 0118 & -0239 & -3.379 & 0001 & 1.000 & 1.000 \\
\hline \multicolumn{9}{|c|}{ End of Term } \\
\hline & \multirow{2}{*}{ Model } & \multicolumn{2}{|c|}{$\begin{array}{l}\text { Unstandardized } \\
\text { Coefficients }\end{array}$} & \multirow{2}{*}{$\begin{array}{c}\text { Standardized } \\
\text { Coefficients }\end{array}$} & \multirow{2}{*}{$\mathrm{t}$} & \multirow{2}{*}{ Sig. } & \multicolumn{2}{|c|}{ Collinearity Statistics } \\
\hline & & B & Std. Error & & & & Tolerance & VIF \\
\hline \multirow{4}{*}{24} & (Constant) & 3.406 & 0.361 & & 9.434 & 0000 & & \\
\hline & $\begin{array}{c}\text { Facial } \\
\text { Expression }\end{array}$ & -0581 & 0204 & -0474 & -2.841 & 0006 & 0329 & 3.035 \\
\hline & Gaze & 0393 & 0191 & 0319 & 2.060 & 0043 & 0382 & 2.619 \\
\hline & $\begin{array}{l}\text { Personal } \\
\text { Attention }\end{array}$ & -0390 & 0142 & -0306 & -2.753 & 0007 & 0741 & 1.350 \\
\hline
\end{tabular}

Source: Prepared by the authors. 
quately detected, was associated to rejection to "hang out with" at the end of the term. In fact, perception and building of impressions based in facial expressions tend to be sustained for a longer period, according to other studies (Mcaleer, Todorov, \& Belin, 2014; North, Todorov, \& Osherson, 2012; Stewart et al., 2012).

Regarding "hang out with" after six months of daily contact, behaviors in the beginning of the term were facial expression, smile, posture, intonation, clarity and speech duration $(\mathrm{F}(6,84)=4.49 ; p=0.001)$. Acceptance to "hang out with" at the end of the term was reduced by facial expression, clarity and speech duration, considered adequate in the beginning of the term, and increased with perception of smiles, posture and intonation (Table 5).

Rejection to "study with" at the end of the term was explained by orientation, speech volume and clarity in the beginning of the term $(\mathrm{F}(5,71)=5.44 ; p=$ $0.000)$. Orientation and volume were negatively related to rejection to "study with", minimizing it after six months of contact and speech clarity tended to increase rejection. Finally, acceptance to "study with" at the end of term, was explained by pitch and speed $(\mathrm{F}(2,87)=4.37 ; p=0.017)$; pitch reduced acceptance and speed increased it, after six months of contact.

\section{Final Considerations}

There were no differences in behaviors in the beginning of the term and at its end, when independently analyzed. However, the way they were ranked as explanations to social acceptance and rejection to "study with" and to "hang out with" changed from the beginning of the term to its end, indicating that contact during term allows for a change in the motives to social acceptance and rejection within the group. There is also the possibility that difference be mediated by individual or group values, which are incorporating in daily contact and affect the ways people justify their choices, despite their perceptions still being the same.

A more detailed analysis of the outliers of the regression can be performed to also identify people whose perceptions have been changed from the beginning to the end of the semester, namely that were accepted at the beginning and they were not the end of the semester or rejected at the beginning and not the end of the semester, since the identification of the characteristics of these people can provide a better insight into the aspects that mediated the change in perception of first impressions.

This work addresses the topic from how accepted and rejected people are perceived by their peers and further research could compare methods to see which one best explains the variability of acceptance and social rejection in the group, whether they are nonverbal behaviors assessed by the perception of pairs or social skills and emotional characteristics assessed by self report.

Among other limitations in this study, we can mention the loss that occurred pre and post test, since not all subjects were in the room at the second time of collection. At the same time, the research took place in a common core of discipline and would be worth taking rooms separately per course to examine the profile of these subjects per course, since the culture of each of these groups 
Table 5. Nonverbal behaviors in the beginning of the term predictive of social acceptance and rejection to "study with" and "hang out with" at the end of the term.

\begin{tabular}{|c|c|c|c|c|c|c|c|c|}
\hline \multicolumn{9}{|c|}{ Rejection to "Hang Out With" } \\
\hline & \multirow{2}{*}{ Model } & \multicolumn{2}{|c|}{$\begin{array}{c}\text { Unstandardized } \\
\text { Coefficients }\end{array}$} & \multirow{2}{*}{$\begin{array}{c}\text { Standardized } \\
\text { Coefficients } \\
\text { Beta }\end{array}$} & \multirow{2}{*}{$\mathrm{t}$} & \multirow{2}{*}{ Sig. } & \multicolumn{2}{|c|}{ Collinearity Statistics } \\
\hline & & B & $\begin{array}{l}\text { Std. } \\
\text { Error }\end{array}$ & & & & Tolerance & VIF \\
\hline \multirow{4}{*}{24} & (Constant) & 3.082 & 0.429 & & 7.180 & 0000 & & \\
\hline & $\begin{array}{c}\text { Facial } \\
\text { Expression }\end{array}$ & -0386 & 0152 & -0404 & -2.532 & 0014 & 0491 & 2.038 \\
\hline & $\begin{array}{l}\text { Personal } \\
\text { Atention }\end{array}$ & 0572 & 0229 & 0481 & 2.495 & 0015 & 0337 & 2.966 \\
\hline & $\begin{array}{l}\text { Answers to } \\
\text { Questions }\end{array}$ & -0497 & 0209 & -0402 & -2.372 & 0021 & 0437 & 2.289 \\
\hline \multicolumn{9}{|c|}{ Acceptance to "Hang Out With" } \\
\hline & \multirow{2}{*}{ Model } & \multicolumn{2}{|c|}{$\begin{array}{c}\text { Unstandardized } \\
\text { Coefficients }\end{array}$} & $\begin{array}{l}\text { Standardized } \\
\text { Coefficients }\end{array}$ & & & \multicolumn{2}{|c|}{ Collinearity Statistics } \\
\hline & & $\mathrm{B}$ & $\begin{array}{l}\text { Std. } \\
\text { Error }\end{array}$ & Beta & l & Jig. & Tolerance & VIF \\
\hline \multirow{7}{*}{21} & (Constant) & 1.349 & 0.247 & & 5.452 & 0000 & & \\
\hline & $\begin{array}{c}\text { Facial } \\
\text { Expression }\end{array}$ & -0184 & 0079 & -0332 & -2.321 & 0023 & 0466 & 2.145 \\
\hline & Smiles & 0238 & 0093 & 0403 & 2.555 & 0013 & 0383 & 2.609 \\
\hline & Posture & 0167 & 0082 & 0291 & 2.025 & 0046 & 0463 & 2.161 \\
\hline & Intonation & -0195 & 0092 & -0359 & -2.116 & 0037 & 0331 & 3.020 \\
\hline & Clarity & -0228 & 0090 & -0438 & -2.548 & 0013 & 0323 & 3.098 \\
\hline & $\begin{array}{c}\text { Speech } \\
\text { Duration }\end{array}$ & 0227 & 0091 & 0444 & 2.502 & 0014 & 0302 & 3.310 \\
\hline \multicolumn{9}{|c|}{ Rejection to "Study With" } \\
\hline & \multirow{2}{*}{ Model } & \multicolumn{2}{|c|}{$\begin{array}{c}\text { Unstandardized } \\
\text { Coefficients }\end{array}$} & $\begin{array}{l}\text { Standardized } \\
\text { Coefficients }\end{array}$ & t & Sig & \multicolumn{2}{|c|}{ Collinearity Statistics } \\
\hline & & $\mathrm{B}$ & $\begin{array}{l}\text { Std. } \\
\text { Error }\end{array}$ & Beta & $l$ & sig. & Tolerance & VIF \\
\hline \multirow{9}{*}{22} & (Constant) & 3.716 & 0.612 & & 6.070 & 0000 & & \\
\hline & Posture & 0438 & 0239 & 0284 & 1.830 & 0072 & 0446 & 2.244 \\
\hline & Orientation & -0993 & 0272 & -0615 & -3.654 & 0001 & 0379 & 2.641 \\
\hline & $\begin{array}{c}\text { Personal } \\
\text { Appearance }\end{array}$ & 0427 & 0250 & 0231 & 1.707 & 0092 & 0587 & 1.703 \\
\hline & $\begin{array}{l}\text { Speech } \\
\text { Volume }\end{array}$ & -0744 & 0268 & -0482 & -2.770 & 0007 & 0354 & 2.822 \\
\hline & Clarity & 0464 & 0204 & 0332 & 2.278 & 0026 & 0506 & 1.978 \\
\hline & \multicolumn{8}{|c|}{ Acceptance to "Study With" } \\
\hline & \multirow{2}{*}{ Model } & \multicolumn{2}{|c|}{$\begin{array}{c}\text { Unstandardized } \\
\text { Coefficients }\end{array}$} & $\begin{array}{l}\text { Standardized } \\
\text { Coefficients }\end{array}$ & & $\operatorname{Sig}$ & \multicolumn{2}{|c|}{ Collinearity Statistics } \\
\hline & & B & $\begin{array}{l}\text { Std. } \\
\text { Error }\end{array}$ & Beta & l & Jig. & Tolerance & VIF \\
\hline \multirow{3}{*}{25} & (Constant) & 1.741 & 0.350 & & 4.976 & 0000 & & \\
\hline & Pitch & -0378 & 0139 & -0430 & -2.723 & 0008 & 0428 & 2.338 \\
\hline & Speed & 0404 & 0144 & 0444 & 2.814 & 0006 & 0428 & 2.338 \\
\hline
\end{tabular}

Source: Prepared by the authors. 
would be different and could tell more about what circumstances the selection of certain nonverbal behaviors as predictors of acceptance and rejection occur.

It should be emphasized that no significant differences were found in the perception of nonverbal behaviors between the female and male participants. Although some authors (Bartholomeu, Montiel, \& Pessotto, 2011; Montiel, Pessotto, \& Bartholomeu, 2014) observed differences between the sexes, the result of the present research may be related to the fact of the differences between selfreported behaviors and based on nonverbal behaviors. However, an in-depth discussion of these data is beyond the scope of this study.

\section{References}

Ambady, N., \& Skowronski, J. (2008). First Impressions. NY: Guilford.

Ames, D. R. (2008). Assertiveness Expectancies: How Hard People Push Depends on the Consequences They Predict. Journal of Personality and Social Psychology, 95, 15411557. https://doi.org/10.1037/a0013334

Aviezer, H., Trope, Y., \& Todorov, A. (2012). Body Cues, Not Facial Expressions, Discriminate between Intense Positive and Negative Emotions. Science, 338, 1225-1229. https://doi.org/10.1126/science.1224313

Bartholomeu, D., \& Montiel, J. M. (2013). Interfaces of Socialization and Social Skills for Social Acceptance and Rejection. Journal of Personality and Social Psychology.

Bartholomeu, D., Carvalho, L. F., Silva, M. C. R., Miguel, F. K., \& Machado, A. A. (2011). Aceitação e rejeição entre pares e habilidades sociais em universitários. Estudos de Psicologia, 16, 155-162. https://doi.org/10.1590/S1413-294X2011000200006

Bartholomeu, D., Montiel, J. M., \& Pessotto, F. (2011). Sociometria e habilidades sociais em alunos do ensino médio. Estudos Interdisciplinares em Psicologia, 2, 211-228. https://doi.org/10.5433/2236-6407.2011v2n2p211

Bierman, K. L., \& Wargo, J. B. (1995). Predicting the Longitudinal Course Associated with Aggressive-Rejected, Aggressive (Nonrejected), and Rejected (Nonaggressive) Status. Development and Psychopathology, 7, 669-682. https://doi.org/10.1017/S0954579400006775

Blake, J. J., Kim, E. S., \& Lease, A. M. (2011). Exploring the Incremental Validity of Nonverbal Social Aggression: The Utility of Peer Nominations. Merrill-Palmer Quarterly, 57, 293-318. https://doi.org/10.1353/mpq.2011.0015

Borod, J. C., Pick, L. H., Hall, S. Sliwinski, M., Madigan, N., Obler, L. K., Welkowitz, J., Canino, E., Erhan, H. M., Goral, M., Morrison, C., \& Tabert, M. (2000). Relationships among Facial, Prosodic, and Lexical Channels of Emotional Perceptual Processing. Cognition and Emotion, 14, 193-211. https://doi.org/10.1080/026999300378932

Caballo, V. (2000). Manual de Avaliação e Treinamento das Habilidades Sociais. São Paulo: Santos.

Davis, M. H., \& Kraus, L. A. (1997). Personality and Empathic Accuracy. In W. Ickes (Ed.), Empathic Accuracy (pp. 144-168). New York, NY: Guilford.

Davitz, J. (1964). The Communication of Emotional Meaning. New York, NY: McGrawHill.

Dockrell, J., \& Mcshane, J. (2000). Crianças com dificuldades de aprendizagem: Uma abordagem cognitiva. Porto Alegre: Artmed.

Funder, D. C., \& Harris, M. J. (1986). Experimental Effects and Person Effects in Delay of Gratification. American Psychologist, 41, 476-477. 
https://doi.org/10.1037/0003-066X.41.4.476

Gallo, S. (2007). Cotidiano escolar: Emergência e invenção. Piracicaba: Jacintha Editores.

Greenfield, P. M., \& Quiroz, B. (2013). Context and Culture in the Socialization and Development of Personal Achievement Values: Comparing Latino Immigrant Families, European American Families, and Elementary School Teachers. Journal of Applied Developmental Psychology, 34, 108-118.

Kouros, C. D., \& Cummings, E. M. (2011). Transactional Relations between Marital Functioning and Depressive Symptoms. American Journal of Orthopsychiatry, 81, 128138. https://doi.org/10.1111/j.1939-0025.2010.01080.x

Kraus, M. W., Oveis, C., Allinson, M. L., Yong, R. C., Tauer, J., \& Keltner, D. (2014). Teasing, Taunting, and the Politics of Politeness: High Sociometric Status Is Associated with Expectation-Consistent Behavior. PLoS ONE, 9, e104737. https://doi.org/10.1371/journal.pone.0104737

Kudesia, R. S., \& Elfenbein, H. A. (2013). Non-Verbal Communication in the Workplace. Nonverbal Communication, 805-832.

Latha, M. (2014). First Impressions: A Study of Non-Verbal Communication. Frontiers of Language and Teaching, 5, 160-163.

Mcaleer, P., Todorov, A., \& Belin, P. (2014). How Do You Say "Hello"? Personality Impressions from Brief Novel Voices, 9, 1-9.

Montiel, J. M., Pessotto, F., \& Bartholomeu, D. (2014). Habilidades sociais e status sociométrico em crianças do ensino fundamental. Revista Sul Americana de Psicologia, 2, 251-273.

Neuliep, J. W. (2003). Intercultural Communication: A Contextual Approach (2nd ed.). New York, NY: Houghton Mifflin.

North, M. S., Todorov, A., \& Osherson, D. N. (2012). Accuracy of Inferring Self- and Other-Preferences from Spontaneous Facial Expressions. Journal of Nonverbal Behavior, 36, 227-233. https://doi.org/10.1007/s10919-012-0137-6

Reiman, T. (2008). The Power of Body Language: How to Succeed in Every Business and Social Encounter. New York, NY: Pocket Books.

Stewart, L. H., Ajina, S., Getov, S., Bahrami, B., Todorov, A., \& Rees, G. (2012). Unconscious Evaluation of Faces on Social Dimensions. Journal of Experimental Psychology: General, 141, 715-727. https://doi.org/10.1037/a0027950

Tetlock, P. E. (1983) Accountability and Complexity of Thought. Journal of Personality and Social Psychology, 45, 74-83. https://doi.org/10.1037/0022-3514.45.1.74

Titkova, V., Ivaniushina, V., \& Alexandrov, D. (2013). Sociometric Popularity in a School Context. Basic Research Program, Working Papers, Series: Education.

Wentzel, K. R. (2009). Students' Relationships with Teachers as Motivational Contexts (pp. 301-322). Handbook of Motivation at School. 
Submit or recommend next manuscript to SCIRP and we will provide best service for you:

Accepting pre-submission inquiries through Email, Facebook, LinkedIn, Twitter, etc. A wide selection of journals (inclusive of 9 subjects, more than 200 journals)

Providing 24-hour high-quality service

User-friendly online submission system

Fair and swift peer-review system

Efficient typesetting and proofreading procedure

Display of the result of downloads and visits, as well as the number of cited articles Maximum dissemination of your research work

Submit your manuscript at: http://papersubmission.scirp.org/

Or contact psych@scirp.org 